\title{
Nipple Carcinoma
}

National Cancer Institute

\section{Source}

National Cancer Institute. Nipple Carcinoma. NCI Thesaurus. Code C28432.

A carcinoma that arises in the area of the nipple. Representative examples include Paget disease and skin squamous cell carcinoma. 